DOI: $10.15593 / 2224-9354 / 2018.4 .7$

УДК 316.032-057.875

\title{
О.А. Ганина
}

\section{ОРГАНИЗАЦИЯ БЫТА В УНИВЕРСИТЕТСКИХ ОБЩЕЖИТИЯХ РАЗНОГО ТИПА}

\begin{abstract}
Статья посвящена анализу особенностей повседневной жизни современных студентов в вузовских общежитиях. Жилищно-бытовые условия являются контекстом для образовательного процесса, они могут оказывать влияние на его ход и результаты. В связи с этим руководству вуза важно понимать актуальное состояние и особенности организации быта студенческой жизни. В работе представлен краткий обзор социологических исследований студенчества последних тридцати лет, но основное внимание авторов сосредоточено на анализе результатов пермского социологического исследования 2016 года, посвященного различным сторонам студенческой жизни.

Исследователями была выявлена специфика организации быта в общежитии с помощью таких показателей, как субъекты, организующие быт студентов, участие студентов в этом процессе, степень удовлетворенности студентов разными сторонами жизни в общежитии, бытовые проблемы и первоочередные меры по улучшению бытовых условий. Результаты исследования демонстрируют наличие влияния особенностей жилищно-бытовых условий в общежитиях на образовательный процесс, а также на активность студентов. В числе прочего эмпирически выявлена связь качества жилищно-бытовых условий с успеваемостью студентов, с числом приносимых студентами предметов культурного и бытового назначения. Благодаря представленности в выборке студентов из общежитий трех типов исследователи выделили особенности студенческой жизни коридорного, блочного и нового типа. Среди таких особенностей рассмотрены материальные аспекты организации быта, роль различных субъектов в организации студенческой жизни в общежитии, наиболее острые проблемы жизни в общежитии по мнению студентов и др.

Ключевые слова: вуз, общежитие, бытовые условия, студенты, анкетный опрос, удовлетворенность, проблемы, меры.
\end{abstract}

Результаты и проблемы высшего образования часто связаны с жилищнобытовыми условиями студенческой жизни. Организация этих бытовых условий у студентов, проживающих в университетском общежитии, во многом зависит от деятельности и решений, предпринимаемых сотрудниками университета.

Предыдущие исследования. В Уральском регионе изучение студенчества осуществляется достаточно активно. Уже более 30 лет социологи публикуют результаты исследований студенчества в Екатеринбурге, Перми, Уфе, Челябинске, Ижевске, Оренбурге и других городов Урала. В 1981 году Л.Я. Рубина, обобщая материалы социологических исследований, проведенных в уральских вузах, анализировала роль студенчества в советской социальной структуре и его участие в общественной жизни, выявляла особенности подготовки специалистов и их социально-профессиональной ориентации [1].

(C) Ганина О.А., 2018

Ганина Ольга Александровна - старший преподаватель кафедры социологии и политологии ФГБОУ ВО «Пермский национальный исследовательский политехнический университет», e-mail: ganinaoa@yandex.ru. 
В Перми на базе современного ПНИПУ проводились социологические исследования студенчества в 1980-х [2] и в 1990-х годах [3]. Ключевыми темами этих исследований были взаимодействия студентов с сотрудниками вуза, роль студенческого самоуправления, социально-психологические особенности студенчества, а также особенности жизни в университетских общежитиях. В 2009 году на базе исследований пермских университетов В.Н. Стегний и Л.Н. Курбатова описали социальный портрет студентов в контексте трансформации общества [4]. Данное исследовательское направление пермской социологии сохраняется и в 2010-х годах в исследованиях В.Н. Стегния [5] и Г.В. Разинского [6].

В разгар эпохи рыночной трансформации российского общества, в 1995 году Л.Я. Рубина в соавторстве с Ю.Р. Вишневским публикуют в книге «Студент - 95: социальный портрет» результаты исследований в нескольких вузах г. Екатеринбурга [7]. Тогда методом анкетного опроса были изучены материальное положение студенчества, уровень профессионального и социального самоопределения, политическая активность, свободное время, взаимоотношения с различными студенческими организациями. Впоследствии в Уральском федеральном университете Екатеринбурга с 1995 по 2012 год прошел шестиэтапный социологический мониторинг: в 1995, 1999, 2003, 2007, 2009, 2012 годах [8-13]. Результаты шестого этапа были опубликованы в 2012 году в сборнике «Студент-2012» [14], где описаны ценности и гражданская культура студенчества, а также практики их образовательной, общественной и досуговой деятельности. На базе этих исследований в 2017 году были представлены серьезные научные обобщения, а также выявление динамики трансформации студенчества за 20 лет [15].

В 2010 и 2011 годах были представлены результаты исследования досуговой жизнедеятельности студентов, проведенных соответственно М.Е. Петровой в Уфе [16] и Г.В. Бобровой в Оренбурге [17]. В это же время Е.М. Харланова на основе данных социологического опроса в различных уральских вузах изучила социальную активность студентов [18]. В 2014 году Е.Г. Черникова опубликовала результаты социологического исследования студенческого самоуправления в Челябинске [19], а в 2015 году А.И. Вишняков, О.С. Карымова, Е.А. Трифонова на материалах исследования выявили этнические особенности ценностных ориентаций студентов Оренбурга [20].

Многие исследователи ставят студенчество в ряд других молодежных групп по основному роду занятий, таких как «учащиеся», «работающие» и «незанятые», и выявляют в разрезе указанных групп особенности структуры ценностей, социально-политической позиции и т.п. Примером таких работ могут служить результаты социологического исследования свободного времени пермской молодежи, опубликованные В.Д. Разинской в 2016 году [21].

Одним из самых масштабных исследований студенчества был московский мониторинг «Российский вуз глазами студентов», осуществленный под 
руководством И.М. Ильинского и В.А. Лукова в 2000-2012 годах в государственных и негосударственных вузах методом опроса, основными целями которого были анализ экономического положения студенческой молодежи, ее социального настроения, жизненных ориентаций, отношения к социальной реальности и активности студентов в различных сферах деятельности [22]. Результаты этих исследований позволили развеять сложившиеся стереотипы о секторе негосударственного образования и показали, что при всем различии состава студентов государственных и негосударственных вузов их отношение к учебе, базовые ценности, удовлетворенность студенческой жизнью, включенность в жизнь вуза, уровень материальной обеспеченности, представление о перспективах и жизненных планах имеют сходную конфигурацию. Эта конфигурация определяется особенностями социально-экономического положения, социокультурными процессами, общественными настроениями в Москве [23].

Это лишь некоторые примеры среди массы исследований студенчества, проведенных в Уральском регионе. История этих исследований превышает 30 лет и охватывает позднесоветский период 1980-х годов, период рыночных реформ 1990-х годов и период стабилизации нулевых и 2010-х годов. В современных условиях существенно растет количество собираемых данных, скорость их обработки и разнообразие инструментов для работы с данными. Однако, несмотря на разнообразие и многочисленность исследований в данной области, недостаточно много уделялось внимания выявлению особенностей бытовых условий жизни студентов в университетских общежитиях и влиянию этих условий на студенческую жизнь.

Описание исследования, метода и выборочной совокупности. В 2016 году в Перми, в общежитиях ПНИПУ было проведено социологическое исследование «Студенчество как первая ступень взрослой жизни». В ходе исследования были рассмотрены такие ключевые особенности современной студенческой жизни, как межличностные отношения, студенческое самоуправление, жилищно-бытовые условия, бюджет времени и виды деятельности студентов, социальная активность студентов, их система ценностей и социальнопсихологические особенности. В данной статье проанализированы результаты исследования, связанные с особенностями жилищно-бытовых условий жизни в университетских общежитиях.

В указанном исследовании, проведенном методом анкетного опроса, приняли участие 608 студентов девяти разных факультетов ПНИПУ. В выборке $52,5 \%$ девушек и 47,5 \% юношей. Кроме того, были представлены студенты всех курсов обучения, при этом $2 / 3$ выборки составили учащиеся младших курсов (63,6 \% опрошенных - учащиеся 1-го и 2-го курсов), треть составили студенты старших курсов (36,4 \% опрошенных - учащиеся 3, 4 и 5-го курсов). Респонденты проживали в университетских общежитиях, заметно различающихся по типу жилищно-бытовых условий. Треть опрошенных (36,2 \%) проживала в студ- 
городке «Балатово» в общежитиях коридорного типа, имеющих самый ранний год постройки. Другая треть респондентов (36,3 \%) проживала в общежитиях блочного типа в студгородке «Комплекс». Почти четверть опрошенных $(23,4 \%)$ являлись жителями общежитий нового типа в студгородке «Комплекс» и 4,1 \% проживали в других общежитиях ПНИПУ.

\section{Анализ результатов исследования.}

Влияние числа соседей по комнате на жизнь студентов. Опрошенные студенты чаще всего проживали в комнатах по 2-3 человека. Почти половина $(44,6 \%)$ делили комнату на двоих с соседом (рис. 1) и столько же - на троих с двумя соседями $(43,4 \%)$. Лишь $5 \%$ опрошенных не имели соседей по комнате, а $7 \%$ респондентов проживали в комнате вчетвером, т.е. имели еще 3 соседей. При этом в общежитиях коридорного типа бо́льшая часть студентов жили по 3 человека в комнате (75,5 \%), а в общежитиях нового типа почти все опрошенные делили комнату на двоих (93\%). В общежитиях же блочного типа половина студентов жили по 2 человека (51,6 \%), а треть - по 3 человека в комнате (36,2 \%).

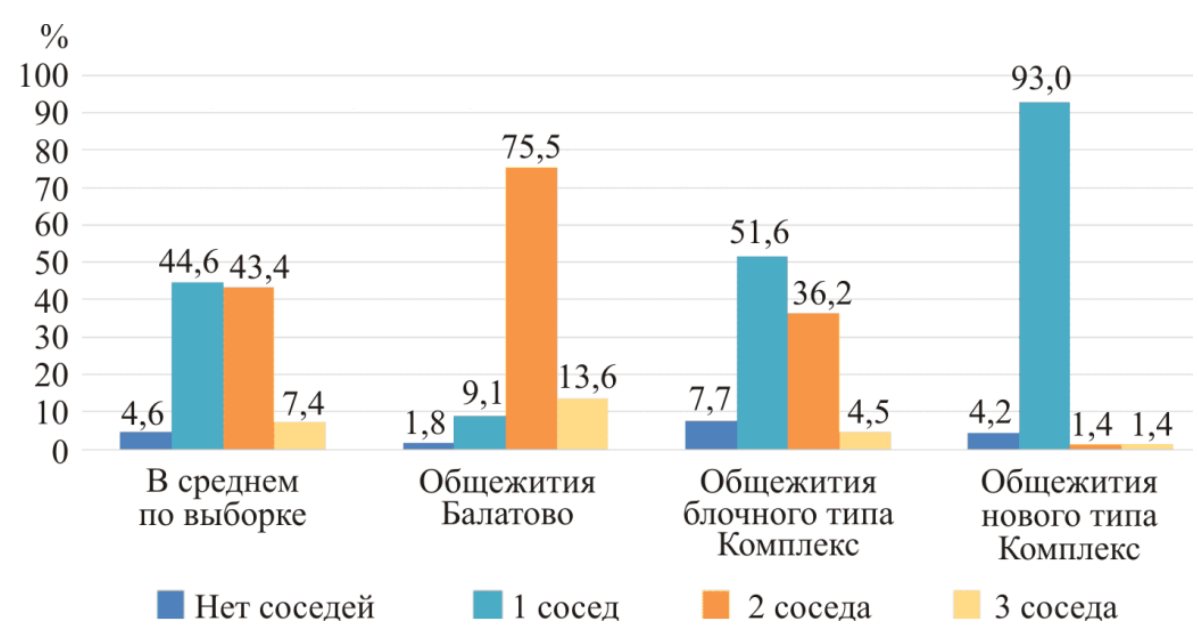

Рис. 1. Число соседей по комнате в среднем по выборке и в различных типах общежития, \% от количества опрошенных

Прослеживается влияние числа соседей по комнате общежития на уровень успеваемости студентов (рис. 2). Доля отличников сокращается с увеличением числа соседей, а хорошистов и троечников - растет. Число соседей влияет и на отношение студента к общежитию: чем больше соседей по комнате, тем больше тех, кто считает общежитие «неизбежным злом», а чем меньше соседей, тем больше считающих общежитие «родным домом».

Основные субъекты организачии студенческого быта в общежитии. В качестве таких субъектов студенты отмечали студсовет $(58,9 \%)$, заведующего общежитием $(50,2 \%)$ и воспитателя $(45,1 \%)$. Влияние вахтера на ход 
жизни в общежитии отметили 7,8 \% студентов, а самих студентов как субъектов, организующих быт, отметили менее 5 \% опрошенных (ответы «самоорганизация» $-2,5 \%$ и «я» $-2,3 \%)$.

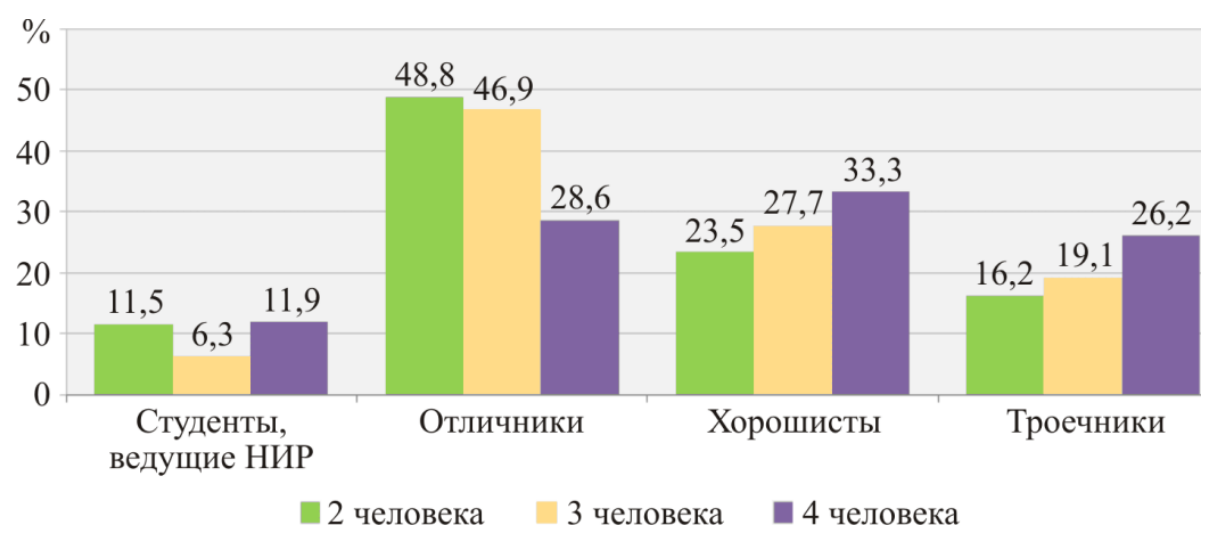

Рис. 2. Успеваемость студентов в зависимости от числа человек, проживающих в одной комнате, \% от количества опрошенных (из-за малочисленности не представлены проживающие без соседей)

Влияние воспитателя вдвое чаще, чем в остальных общежитиях, отмечали студенты в общежитиях коридорного типа (рис. 3). Роль заведующего общежитием вдвое чаще отмечали в общежитиях блочного и нового типов, чем в общежитиях коридорного типа. Кроме того, вахтера называли организатором студенческой бытовой жизни заметно чаще студенты общежитий блочного типа, чем общежитий коридорного и нового типа.

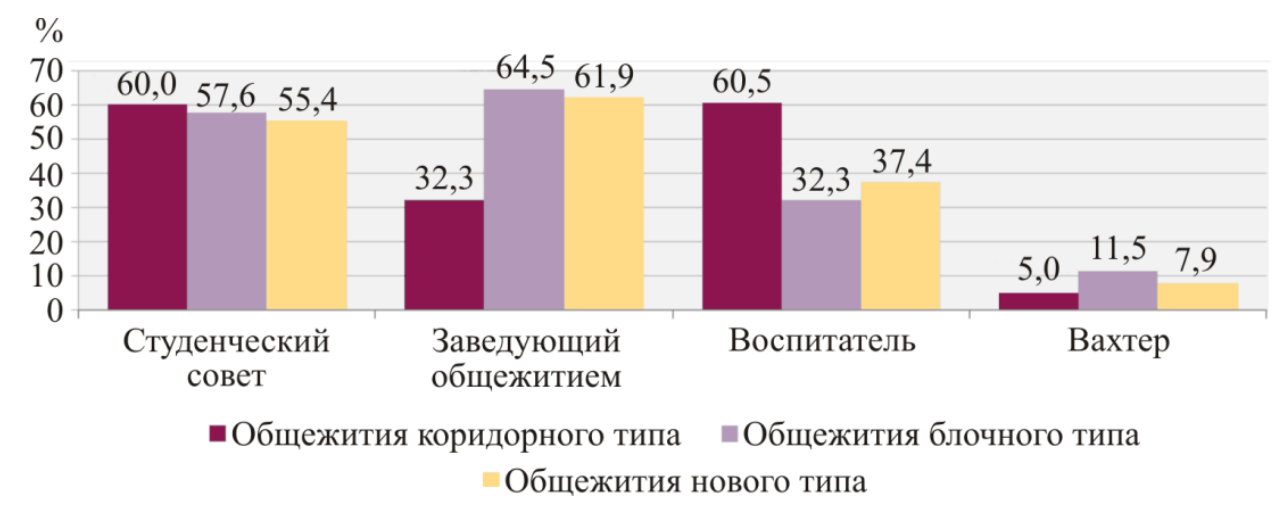

Рис. 3. Мнения о том, кто организует жизнь в общежитии, в зависимости от типа общежития, \% от количества опрошенных

Удовлетворенность различными сторонами жизни общежития. Наиболее удовлетворены студенты отношениями с работниками: этими отношениями в целом довольны 72,5 \% опрошенных (рис. 4). 


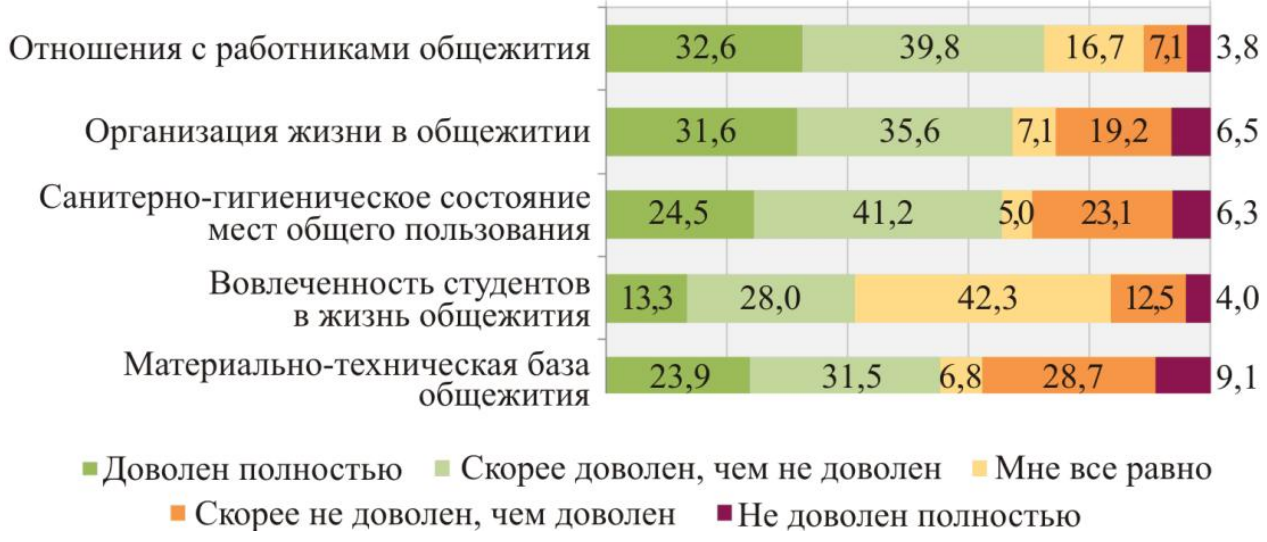

Рис. 4. Удовлетворенность студентов разными сторонами жизни в общежитии, \% от количества опрошенных

На втором и третьем месте по степени удовлетворенности оказались организация жизни в общежитии, которой удовлетворены 67,2 \% студентов, и санитарно-гигиеническое состояние мест общего пользования, которым удовлетворены $65,6 \%$ студентов.

Вовлеченность студентов в жизнь общежития оставляла респондентов либо довольными (42,3 \%), либо равнодушными (40 \%), т.е. уровень студенческого безразличия в отношении своей вовлеченности в жизнь общежития очень высок.

В отношении материально-технической базы общежития мнения опрошенных разделились кардинальнее всего: более половины высказались о ней положительно (55,4 \%), однако доля критикующих именно эту сторону жизни максимальна в сравнении с остальными сторонами жизни общежития более трети опрошенных недовольны ею $(37,8 \%)$.

В разрезе разных типов общежитий выяснилось, что в целом самый низкий уровень недовольства был у студентов общежитий нового типа, а самый высокий - в общежитиях коридорного типа (рис. 5).

В общежитиях нового типа у студентов выше всего удовлетворенность материально-технической базой (93 \%), а сетуют студенты в основном на свою низкую вовлеченность в жизнь общежития (20,8 \%). По остальным сторонам жизни уровень недовольства здесь низкий, около 7-11\%. При этом недовольство выше, чем в других общежитиях, только по показателю вовлеченности студентов в жизнь общежития, и здесь же был ниже уровень безразличия к этой вовлеченности (36 \%, тогда как в остальных общежитиях 41-47 \%). Это позволяет предположить, что у студентов вместе с высокой удовлетворенностью материальными и социальными сторонами жизни в общежитии появляется стремление активно включаться в его жизнь.

В общежитиях блочного типа студенты были наиболее довольны отношениями с работниками и организацией жизни (около 80 \%). Недовольны 
жители чаще всего материально-технической базой $(43,2$ \%) и санитарногигиеническим состоянием мест общего пользования (27,8 \%). В целом уровень недовольства в общежитиях блочного типа был на среднем уровне почти по всем показателям, кроме отношений с работниками и вовлеченности студентов, по которым уровень недовольства был низкий.

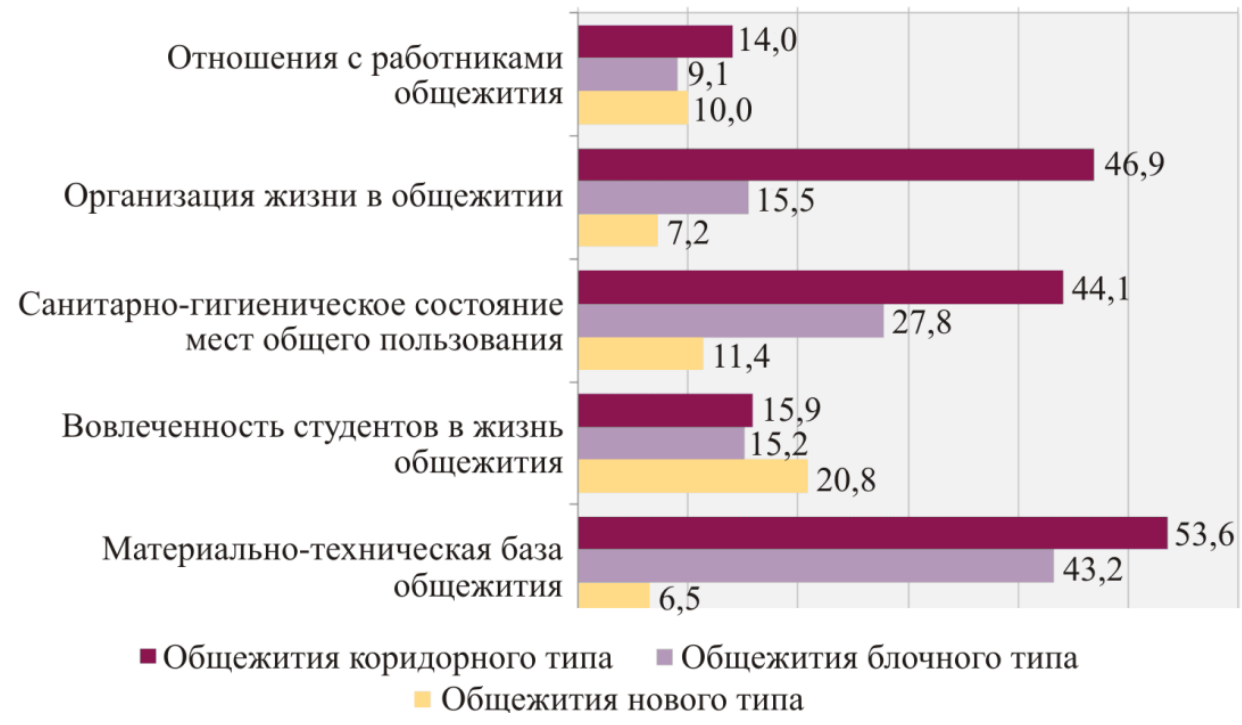

Рис. 5. Уровень недовольства студентов определенными сторонами жизни в общежитиях разного типа (ответы «недоволен» и «скорее не доволен»), \% среди групп по типу общежитий

В общежитиях коридорного типа жители удовлетворены отношениями с работниками (60\%), а недовольны - материально-технической базой $(53,6 \%)$, организацией жизни в общежитии $(46,9 \%)$ и санитарно-гигиеническим состоянием мест общего пользования $(44,1 \%)$. Здесь самый высокий уровень неудовлетворенности в сравнении с остальными общежитиями. В отличие от общежитий блочного типа, где тоже высок уровень недовольства материально-технической базой, в общежитиях коридорного типа в 1,5 раза выше уровень недовольства санитарно-гигиеническим состоянием мест общего пользования и в 3 раза выше уровень неудовлетворенности организацией жизни в общежитии. Даже в целом небольшая доля недовольных отношениями с работниками (14 \%) здесь выше, чем в других общежитиях, где таких 9-10\%. При этом здесь роль заведующего общежитием в организации жизни была оценена студентами вдвое ниже, чем в остальных общежитиях, а роль воспитателя - вдвое выше.

Наиболее острые проблемы в общежитиях. Более трети опрошенных жаловались на теплоснабжение (39,9\%), множество запретов и ограничений $(37,3 \%)$ и слишком строгий контроль на вахте $(34,0 \%)$. Около четверти отмечали плохие санитарно-гигиенические условия $(26,8 \%)$ и перенаселенность 
$(22,4 \%)$. Многие лишены возможности стирать, сушить и гладить $(15,3 \%)$, указывают на проблемы электроснабжения $(14,8 \%)$ и отсутствие культурного досуга $(13,1 \%)$. От 5 до 8 \% опрошенных отметили невозможность приготовить еду, пьянство студентов, газоснабжение, нарушения общественного порядка посторонними лицами, отсутствие условий для подготовки к занятиям. Реже всего студенты жаловались на проживание лиц, не имеющих на это права $(3,1 \%)$, и отсутствие освещения в общественных местах $(0,2 \%)$.

Актуальность проблем сильно варьируется в зависимости от типа общежития (рис. 6). Так, в общежитиях коридорного типа чаще, чем в других, отмечали плохие санитарно-гигиенические условия, перенаселенность, электроснабжение, невозможность ухода за одеждой, невозможность приготовить еду и газоснабжение. В общежитиях блочного типа чаще, чем в других, жаловались на проблемы теплоснабжения и невозможность постирать, посушить и погладить одежду. В общежитиях нового типа студентов чаще беспокоили избыток ограничений, слишком строгий контроль на вахте и отсутствие культурного досуга.

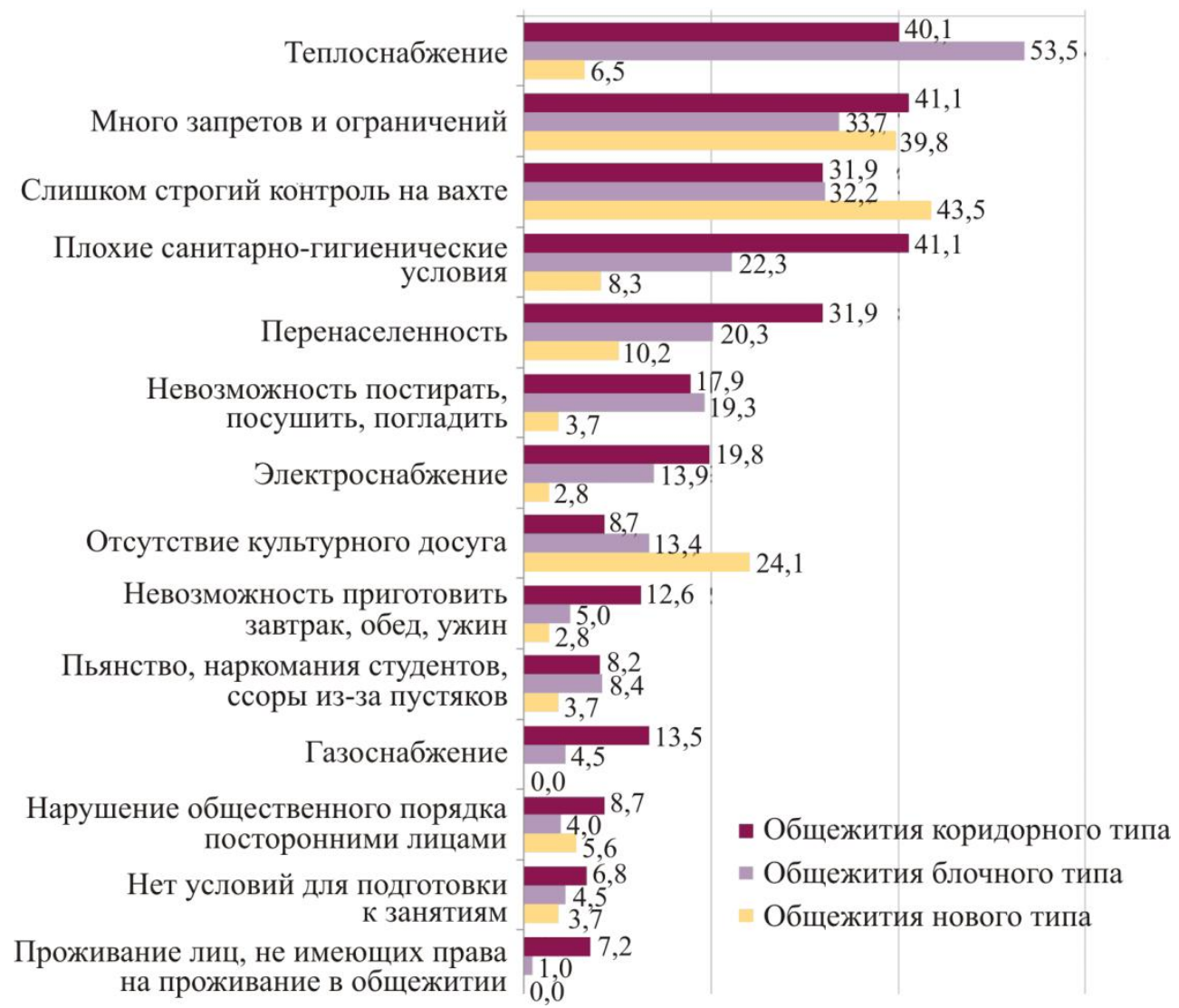

Рис. 6. Проблемы в общежитии, наиболее волнующие студентов, в зависимости от типа общежития, \% среди групп по типу общежитий 
Первоочередные меры в общежитии, предлагаемые студентами. Основная часть опрошенных $(65,9 \%)$ отмечали необходимость буфета, ремонта кухни, санузлов, а также замены мебели и электропроводки. Четверть жителей $(24,8$ \%) просили оборудовать на каждом этаже комнаты для занятий, 17,8 \% - организовать студенческий отряд по контролю за порядком в общежитии, 16,2 \% - выселить всех не имеющих права на проживание. Часто предлагали переизбрать студсовет $(13,5 \%)$ и строже спрашивать с сотрудников $(11,1 \%)$.

Помимо этих мер, предложенных для выбора респондентам в вариантах ответа, студенты сформулировали следующие необходимые по их мнению меры: организовать столовую в общежитии или рядом, улучшить санузлы и душевые, сделать тренажерный или спортивный зал, уменьшить контроль, оставлять гостей на ночь, отменить комендантский час, разрешить домашних животных, организовывать конкурсы чистоты, прививать порядок, улучшить отопление, отремонтировать электропроводку, повышать культуру общения, улучшить кухни, организовать камеру хранения.

В общежитиях коридорного и блочного типа вдвое чаще, чем в общежитиях нового типа, просили позаботиться о буфете, ремонте кухни, санузлов, мебели и электропроводке. В общежитиях коридорного типа, где более острой в сравнении с другими общежитиями была проблема перенаселенности, чаще, чем в других, предлагали такие меры, как выселение из общежития лиц, не имеющих права на проживание, а также строже спрашивать с сотрудников общежития. В общежитиях блочного типа чаще просили оборудовать комнаты для занятий на каждом этаже. При этом здесь заметно реже называли такие меры, как переизбрание студсовета и более строгий спрос с сотрудников общежития. В общежитии нового типа, где ранее было выявлено стремление студентов участвовать в жизни общежития, чаще предлагали создать студенческий отряд по контролю за порядком.

Жилищно-бытовые особенности общежитий различного типа. На основе рассмотренных данных была составлена сравнительная характеристика бытовых условий жизни в общежитиях различного типа (таблица).

1. Общежития коридорного типа. Студенты чаще всего проживают по 3 человека в комнате. Наибольшее число предметов в комнатах у тех студентов, которые относятся к общежитию как к родному дому. Уровень конфликтности студентов по поводу бытовых дел в 2,5 раза выше, чем в других общежитиях. Здесь же максимальная доля недовольных материальнотехнической базой, состоянием мест общего пользования и организацией жизни общежития, а также самый высокий уровень равнодушия к вовлеченности студентов в жизнь общежития и к отношениям с сотрудниками.

2. Общежития блочного типа. Половина проживающих здесь студентов делят комнаты на двоих и треть - на троих человек. Уровень удовлетворенности студентов разными сторонами быта здесь на среднем уровне, при этом 
сильнее всего недовольны материально-технической базой, а наиболее довольны отношениями с работниками и организацией жизни.

3. Общежития нового типа. Почти все студенты живут по 2 человека в комнате. Среднее число предметов культурного и бытового назначения в комнатах заметно меньше, чем в других общежитиях, а наибольшее число таких предметов в комнатах студентов, считающих общежитие неизбежным злом (в других общежитиях наоборот). Проживающие здесь имеют наибольший уровень удовлетворенности жилищно-бытовыми условиями и наименьший уровень безразличия; студенты здесь чаще всего недовольны их вовлеченностью в жизнь общежития.

Сравнительная характеристика бытовых условий жизни студентов в различных типах общежитий ПНИПу

\begin{tabular}{|c|c|c|c|}
\hline Показатель & Коридорный тип & Блочный тип & Новый тип \\
\hline $\begin{array}{l}\text { Среднее число } \\
\text { жителей в комнатах }\end{array}$ & 3,01 & 2,38 & 2,00 \\
\hline $\begin{array}{l}\text { Среднее число } \\
\text { предметов в комнате }\end{array}$ & 4,50 & 4,45 & 3,06 \\
\hline $\begin{array}{l}\text { Субъекты организа- } \\
\text { ции бытовой жизни, } \\
\text { которых называли } \\
\text { чаще, чем в других } \\
\text { типах общежития } \\
\end{array}$ & $\begin{array}{c}\text { Студсовет } \\
\text { и воспитатель }\end{array}$ & $\begin{array}{c}\text { Заведующий } \\
\text { общежитием } \\
\text { и вахтер }\end{array}$ & $\begin{array}{l}\text { Заведующий } \\
\text { общежитием }\end{array}$ \\
\hline $\begin{array}{l}\text { Уровень удовлетво- } \\
\text { ренности разными } \\
\text { сторонами жизни } \\
\text { общежития } \\
\end{array}$ & Низкий & Средний & Высокий \\
\hline $\begin{array}{l}\text { Стороны жизни об- } \\
\text { щежития, которыми } \\
\text { более всего недо- } \\
\text { вольны студенты }\end{array}$ & $\begin{array}{l}\text { - Материально- } \\
\text { техническая база } \\
\text { - Санитарно- } \\
\text { гигиеническое со- } \\
\text { стояние мест общего } \\
\text { пользования } \\
\text { - Организация жизни } \\
\text { общежития }\end{array}$ & $\begin{array}{l}\text { - Материально- } \\
\text { техническая база } \\
\text { • Санитарно- } \\
\text { гигиеническое со- } \\
\text { стояние мест обще- } \\
\text { го пользования }\end{array}$ & $\begin{array}{l}\text { - Вовлеченность } \\
\text { студентов в жизнь } \\
\text { общежития }\end{array}$ \\
\hline $\begin{array}{l}\text { Самые острые } \\
\text { проблемы } \\
\text { в общежитии }\end{array}$ & $\begin{array}{l}\text { - Плохие санитарно- } \\
\text { гигиенические усло- } \\
\text { вия } \\
\text { • Перенаселенность } \\
\text { - Электроснабжение } \\
\text { - Невозможность } \\
\text { ухода за одеждой } \\
\text { - Невозможность } \\
\text { приготовить еду } \\
\text { - Газоснабжение } \\
\end{array}$ & $\begin{array}{l}\text { • Теплоснабжение } \\
\text { • Невозможность } \\
\text { постирать, посу- } \\
\text { шить и погладить } \\
\text { одежду }\end{array}$ & $\begin{array}{l}\text { - Избыток ограни- } \\
\text { чений } \\
\text { • Слишком строгий } \\
\text { контроль на вахте } \\
\text { • Отсутствие куль- } \\
\text { турного досуга }\end{array}$ \\
\hline
\end{tabular}


Окончание таблицы

\begin{tabular}{|c|c|c|c|}
\hline Показатель & Коридорный тип & Блочный тип & Новый тип \\
\hline $\begin{array}{l}\text { Первоочередные } \\
\text { меры, предлагаемые } \\
\text { чаще, чем в осталь- } \\
\text { ных типах } \\
\text { общежитий }\end{array}$ & $\begin{array}{l}\text { • Позаботиться о } \\
\text { буфете, ремонте кух- } \\
\text { ни, санузлов, мебели } \\
\text { и электропроводке } \\
\text { • Выселение лиц, не } \\
\text { имеющих права на } \\
\text { проживание } \\
\text { • Строже спрашивать } \\
\text { с сотрудников обще- } \\
\text { жития }\end{array}$ & $\begin{array}{l}\text { - Позаботиться } \\
\text { о буфете, ремонте } \\
\text { кухни, санузлов, } \\
\text { мебели и электро- } \\
\text { проводке } \\
\text { • Оборудовать } \\
\text { комнаты для заня- } \\
\text { тий на каждом эта- } \\
\text { же }\end{array}$ & $\begin{array}{l}\text { • Создание студен- } \\
\text { ческого отряда по } \\
\text { контролю порядка } \\
\text { • Переизбрать } \\
\text { студсовет }\end{array}$ \\
\hline
\end{tabular}

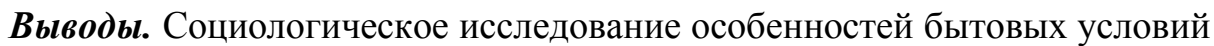
жизни в общежитиях ПНИПУ, проведенное в 2016 году, является одним из целого ряда исследований студенчества последних тридцати лет. Тематика и география таких исследований весьма разнообразна, при этом интерес к студенчеству, как к социальной группе, в современных условиях растет, а социологические опросы часто используются как метод обратной связи сотрудников университета с учащимися.

В ходе опроса 2016 года в общежитиях ПНИПУ выяснилось, что с улучшением жилищно-бытовых условий повышается успеваемость, сокращается число предметов культурного и бытового назначения, приносимые студентами в комнаты, восприятие общежития сдвигается от «неизбежного зла» в сторону сначала «временного жилья», а затем «родного дома», а желания студентов в отношении улучшения жизни в общежитии перераспределяется от материально-технических аспектов к культурно-досуговой жизнедеятельности.

Чаще всего студенты ПНИПУ проживают по 2-3 человека в комнате: на троих комнату чаще делят в общежитиях коридорного типа, на двоих - в общежитиях нового типа. Основные субъекты организации студенческого быта в общежитии - это студсовет, заведующий общежитием и воспитатель. Влияние воспитателя вдвое чаще отмечали в общежитиях коридорного типа, а роль заведующего общежитием - в общежитиях блочного и нового. Сами студенты, по их мнению, не являются субъектом, организующим быт в общежитии.

Наиболее удовлетворены студенты в общежитиях (3/4 опрошенных) отношениями с работниками, высокий уровень удовлетворенности (2/3 опрошенных) организацией жизни в общежитии и санитарно-гигиеническим состоянием мест общего пользования. Наибольшее недовольство (треть опрошенных) отмечается в связи с материально-технической базой общежития, а безразличное отношение чаще всего отмечалось к вовлеченности студентов в жизнь общежития (чуть меньше половины опрошенных). 


\section{Список литературы}

1. Рубина Л.Я. Советское студенчество: Социологический очерк. - М.: Мысль, 1981. - 207 с.

2. Дом, в котором ты живешь: отчет о науч.-исслед. работе / Перм. политехн. ин-т. - Пермь, 1981. -164 с.

3. Некоторые социологические проблемы высшего образования: отчет о науч.-исслед. работе / Перм. политехн. ин-т. - Пермь, 1993. - 93 с.

4. Стегний В.Н., Курбатова Л.Н. Социальный портрет студенчества в условиях трансформации и российского общества. - Пермь: Изд-во Перм. гос. техн. ун-та, 2009. - 384 с.

5. Стегний В.Н. Удовлетворенность молодежи различными сторонами городской жизни // Вестник Пермского национального исследовательского политехнического университета. Социально-экономические науки. - 2016. № 3. - С. 98-108.

6. Разинский Г.В. Молодежь в городе: истоки, состояние, тенденции // Вестник Пермского национального исследовательского политехнического университета. Социально-экономические науки. - 2016. - № 3. - С. 73-88.

7. Вишневский Ю.Р., Рубина Л.Я. Социальный облик студенчества 90-х годов // Социологические исследования. - 1997. - № 10. - С. 56-69.

8. Студент-95: Социальный портрет: информ.-аналит. отчет по материалам социол. исслед. / Ю.Р. Вишневский, В.Т. Шапко [и др.]. - Екатеринбург: СВАПОС, 1995. $-52 \mathrm{c}$.

9. Вишневский Ю.Р., Шапко В.Т. Студент 90-х - социокультурная динамика // Социологические исследования. -2000 . - № 12. - С. 56-63.

10. Формирование системы воспитательной работы в вузе / Ю.Р. Вишневский, С.С. Набойченко, А.В. Пономарев, Л.А. Рапопорт, А.В. Титов // Актуальные проблемы социологии и менеджмента: общество - управление образование - молодежь - культура. - Екатеринбург: Изд-во УГТУ_УПИ, 2004. - Вып. 6. - С. 78-85.

11. Вишневский Ю.Р., Осипчукова Е.В. Адаптация студентов 1 курса: социологический анализ // Внеучебная работа со студентами: опыт, проблемы, перспективы: тез. докл. межрегион. науч.-практ. конф. - Екатеринбург: Изд-во УГТУ-УПИ, 2007. - С. 50-58.

12. Вишневский Ю.Р., Кетов Л.Л. Проблемы становления информационной культуры учащейся молодежи // Актуальные проблемы социологии молодежи / под общ. ред. Ю.Р. Вишневского; Урал. федер. ун-т. - Екатеринбург, 2010. - С. 133-149.

13. Штрихи портрета студента УГТУ-УПИ на фоне мониторинга свердловских студентов / О.Р. Белова, Л.Н. Боронина, Ю.Р. Вишневский, Н.С. Лопаева // Внеучебная работа со студентами: опыт, проблемы, перспективы: тез. докл. науч.-практ. конф. - Екатеринбург: Изд-во УГТУ-УПИ, 2010. - С. 34-42. 
14. Студент-2012: материалы шестого этапа социол. мониторинга / под ред. Ю.Р. Вишневского; Урал. федер. ун-т. - Екатеринбург, 2012. - 332 с.

15. Студент 1995-2016 гг.: динамика социокультурного развития студенчества Среднего Урала / Л.Н. Банникова [и др.]; под общ. ред. Ю.Р. Вишневского; Урал. федер. ун-т. - Екатеринбург, 2017. - 904 с.

16. Петрова М.Е. Особенности досуговой жизнедеятельности студентов: социологический анализ // Сервис plus. - 2011. - № 3. - C. 43-48.

17. Боброва Г.В. Основные проблемы организации досуга студенческой молодежи, на примере Оренбургского государственного университета // Психология и педагогика: методика и проблемы практического применения. 2011. - № 23. - С. 380-384.

18. Харланова Е. М. Исследование социальной активности студентов // Историческая и социально-образовательная мысль. - 2011. - Вып. № 5. - С. 173-178.

19. Черникова Е.Г. Состояние студенческого самоуправления в вузе (на материалах социологических исследований) // Вестник Челябинского государственного педагогического университета. - 2014. - № 4 - С. 165-176.

20. Вишняков А.И., Карымова О.С., Трифонова Е.А. Особенности ценностной сферы студентов русской и татарской этнической принадлежности (на примере Оренбургского государственного университета) // Фундаментальные исследования. - 2015. - № 2 (ч. 10) - С. 2248-2252.

21. Разинская В.Д. Свободное время пермской молодежи // Вестник Пермского национального исследовательского политехнического университета. Социально-экономические науки. - 2016. - № 3. - С. 89-97.

22. Ильинский И.М., Луков В.А. Российский вуз глазами студентов. M., 2005. $-88 \mathrm{c}$.

23. Гневашева В.А., Луков С.В. Российский вуз глазами студентов // Знание. Понимание. Умение. - 2015. - № 3. - С. 322-332.

\section{References}

1. Rubina L.Ia. Sovetskoe studenchestvo: Sotsiologicheskii ocherk [Soviet students: A sociological essay]. Moscow, Mysl', 1981, 207 p.

2. Dom, v kotorom ty zhivesh': otchet o nauch.-issled. rabote [The house you live in: The research report]. Perm, Perm Polytechnic Institute, 1981, 164 p.

3. Nekotorye sotsiologicheskie problemy vysshego obrazovaniia: otchet o nauch.-issled. rabote [Some sociological problems of higher education: The research report]. Perm, Perm Polytechnic Institute, 1993, 93 p.

4. Stegnii V.N., Kurbatova L.N. Sotsial'nyi portret studenchestva v usloviiakh transformatsii i rossiiskogo obshchestva [Social portrait of students in the conditions of transformation in Russian society]. Perm, Perm State Technical University, 2009, 384 p. 
5. Stegnii V.N. Udovletvorennost' molodezhi razlichnymi storonami gorodskoi zhizni [Youth satisfaction with various aspects of urban life]. PNRPU Sociology and Economics Bulletin, 2016, no. 3, pp. 98-108.

6. Razinskii G.V. Molodezh' v gorode: istoki, sostoianie, tendentsii [The youth in the city: origins, status and trends]. PNRPU Sociology and Economics Bulletin, 2016, no. 3, pp. 73-88.

7. Vishnevskii Iu.R., Rubina L.Ia. Sotsial'nyi oblik studenchestva 90-kh godov [Social image of students of the 1990s]. Sotsiologicheskie issledovaniia, 1997, no. 10, pp. 56-69.

8. Vishnevskii Iu.R., Shapko V.T. [et al.]. Student-95: Sotsial'nyi portret: inform.-analit. otchet po ma-terialam sotsiol. issled. [Student-95. Social portrait: The research report]. Yekaterinburg, SVAPOS, 1995, $52 \mathrm{p}$.

9. Vishnevskii Iu.R., Shapko V.T. Student 90-kh - sotsiokul'turnaia dinamika [Students of $1990 \mathrm{~s}$ - socio-cultural dynamics]. Sotsiologicheskie issledovaniia, 2000, № 12, pp. 56-63.

10. Vishnevskii Iu.R., Naboichenko S.S., Ponomarev A.V., Rapoport L.A., Titov A.V. Formirovanie sistemy vospitatel'noi raboty v vuze [Formation of the system of educational work at the university]. Aktual'nye problemy sotsiologii $i$ menedzhmenta: obshchestvo - upravlenie - obrazovanie - molodezh' - kul'tura. Yekaterinburg, Ural State Technical University, 2004. Vol. 6, pp. 78-85.

11. Vishnevskii Iu.R., Osipchukova E.V. Adaptatsiia studentov 1 kursa: sotsiologicheskii analiz [Adaptation of 1st year students: sociological analysis]. Vneuchebnaia rabota so studentami: opyt, problemy, perspektivy. Conference Proceedings. Yekaterinburg, Ural State Technical University, pp. 50-58.

12. Vishnevskii Iu.R., Ketov L.L. Problemy stanovleniia informatsionnoi kul'tury uchashcheisia molodezhi [Problems of formation of information culture of students]. Aktual'nye problemy sotsiologii molodezhi. Ed. Iu.R. Vishnevskii. Yekaterinburg, Ural Federal University, 2010, pp. 133-149.

13. Belova O.R., Boronina L.N., Vishnevskii Iu.R., Lopaeva N.S. Shtrikhi portreta studenta UGTU-UPI na fone monitoringa sverdlovskikh studentov [Strokes of a USTU student portrait (the case of Sverdlovsk students)]. Vneuchebnaia rabota so studentami: opyt, problemy, perspektivy. Conference Proceedings. Yekaterinburg, Ural State Technical University, 2010, pp. 34-42.

14. Student-2012: materialy shestogo etapa sotsiol. monitoringa [Student-2012: materials of the sixth stage of sociological monitoring]. Ed. Iu.R. Vishnevskii. Yekaterinburg, Ural Federal University, 2012, 332 p.

15. Bannikova L.N. [et al.]. Student 1995-2016 gg.: dinamika sotsiokul'turnogo razvitiia studenchestva Srednego Urala [Students in 1995-2016: dynamics of social and cultural development of students of the Middle Urals]. Ed. Iu.R. Vishnevskii. Yekaterinburg, Ural Federal University, Yekaterinburg, 2017, 904 p. 
16. Petrova M.E. Osobennosti dosugovoi zhiznedeiatel'nosti studentov: sotsiologicheskii analiz [Features of leisure activity of students: sociological analysis]. Servis plus, 2011, no. 3, pp. 43-48.

17. Bobrova G.V. Osnovnye problemy organizatsii dosuga studencheskoi molodezhi, na primere Orenburgskogo gosudarstvennogo universiteta [The main problems of the organization of student leisure (the case of Orenburg State University)]. Psikhologiia i pedagogika: metodika i problemy prakticheskogo primeneniia, 2011, no. 23, pp. 380-384.

18. Kharlanova E.M. Issledovanie sotsial'noi aktivnosti studentov [Research of social activity of students]. Istoricheskaia $i$ sotsial'no-obrazovatel'naia mysl', 2011, vol. 5, pp. 173-178.

19. Chernikova E.G. Sostoianie studencheskogo samoupravleniia v vuze (na materialakh sotsiologicheskikh issledovanii) [The state of development of student government in the university (on the materials of sociological research)]. Vestnik Cheliabinskogo gosudarstvennogo pedagogicheskogo universiteta, 2014, no. 4, pp. 165-176.

20. Vishniakov A.I., Karymova O.S., Trifonova E.A. Osobennosti tsennostnoi sfery studentov russkoi i tatarskoi etnicheskoi prinadlezhnosti (na primere Orenburgskogo gosudarstvennogo universiteta) [Particular values of students Orenburg State University, Russian and Tatar ethnicity (on the example of the Orenburg State University)]. Fundamental'nye issledovaniia, 2015, no. 2 (vol. 10), pp. 2248-2252.

21. Razinskaia V.D. Svobodnoe vremia permskoi molodezhi [Free time of Perm youth]. PNRPU Sociology and Economics Bulletin, 2016, no. 3, pp. 89-97.

22. Il'inskii I.M., Lukov V.A. Rossiiskii vuz glazami studentov [Russian university through the eyes of students]. Moscow, 2005, $88 \mathrm{p}$.

23. Gnevasheva V.A., Lukov S.V. Rossiiskii vuz glazami studentov [Russian university through the eyes of students]. Znanie. Ponimanie. Umenie, 2015, no. 3, pp. 322-332.

Оригинальность $94 \%$

Получено 06.03.2018 Принято 30.03.2018 Опубликовано 28.12.2018

\author{
O.A. Ganina
}

\title{
ORGANISING THE WAY OF LIFE IN UNIVERSITY DORMITORIES OF VARIOUS TYPES
}

The paper is devoted to the analysis of the modern student's everyday life in university dormitories. Living conditions have effect on the educational process, and therefore could alter its course and results. In this regard, it looks important for the university administration to understand the current state and peculiarities of the student life organization. The paper presents a brief review of the sociological 
research of students during last thirty years, but the main attention is focused on the results of the 2016 Perm sociological survey devoted to various aspects of student life.

The specificity of the everyday life organization in dormitories of various types has been investigated by researchers using such indicators as people responsible for everyday life, student's participation, students' satisfaction with different aspects of dormitory life, everyday problems and priority measures to improve the living conditions. The research results demonstrate how the everyday life in university dormitories influence the educational process and students' activity. Researchers empirically revealed relations between the level of housing conditions and academic achievements, with the number of cultural and household items brought by students. The sample covering three types of dormitories, the characteristics were identified of student life in the dormitories of the corridor, block and new types. Considered were material aspects of life organization, the role of various actors in the organization of student dormitory life, the most acute problems of dormitory life from the student perspective.

Keywords: university, dormitory, living conditions, students, questionnaire survey, satisfaction, problems, measures.

Olga A. Ganina - Senior Lecturer, Department of Sociology and Politology, Perm National Research Polytechnic University, e-mail: ganinaoa@yandex.ru.

Received 06.03.2018 Accepted 30.03.2018 Published 28.12.2018 